\title{
CHARACTERISTICS OF THE NURSES' WORK PROCESS IN THE FAMILY HEALTH STRATEGY
} CARACTERÍSTICAS DO PROCESSO DE TRABALHO DO ENFERMEIRO DA ESTRATÉGIA
DE SAÚDE DA FAMÍLIA

\author{
CARACTERÍSTICAS DEL PROCESO DE TRABAJO DE ENFERMERÍA DE LA ESTRATEGIA \\ SALUD DE LA FAMILIA
}

\author{
Marcilene de Paula ${ }^{1} \quad{ }^{1}$ Nurse. Curitiba, PR - Brazil. \\ Aida Maris Peres ${ }^{2} \quad{ }^{2}$ Nurse. PhD in Nursing. Adjunct Professor at Universidade Federal do Paraná-UFPR. Member of the \\ Elizabeth Bernardino ${ }^{3} \quad$ Management, Policies and Practices in Health Research Group-GPPGPS UFPR. Curitiba, PR - Brazil. \\ Elizabete Araújo Eduardo ${ }^{4} \quad{ }^{3}$ Nurse. PhD in Nursing. Professor at the Department of Nursing, UFPR. Head of the GPPGPS at \\ UFPR. Curitiba, PR - Brazil. \\ ${ }^{4}$ Nurse. Doctoral student with the Nursing Graduate Program at UFPR. Member of the GPPGPS \\ at UFPR. Coordinator of the Center for Studies in Teaching and Research in Health at Hospital \\ Infantil Waldemar Monastier. Curitiba, PR - Brazil. \\ ${ }^{5}$ Nurse. Doctoral student with the Nursing Graduate Program at UFPR. Member of the GPPGPS \\ at UFPR. Curitiba, PR - Brazil. \\ ${ }^{6} \mathrm{PhD}$ in Education. Professor at the Department of Nursing, UFPR. Member of the Center for \\ Studies in Public Health at UFPR. Curitiba, PR - Brazil.
}

Corresponding Author: Elizabete Araújo Eduardo. E-mail: beteokale@yahoo.com.br Submitted on: 04/23/2013 Approved on:04/03/2014

\begin{abstract}
Descriptive qualitative research study that used non-participant systhematic observation techniques for data collection. The study aimed to characterize the work activities undertaken by nurses who work in the Family Health Strategy (FHS) in a health unit in a city in southern Brazil, according to the five dimensions of the work process in nursing: political participation, assistance, management, research and teaching. The work activities of four nurses were observed and recorded for a week. The results were analyzed and categorized according to the five dimensions of the nursing work process, according to object and aims, respectively. Nurses spent more time in the assistance dimension ( $41.9 \%$ ), followed by management (32.5\%), teaching (20\%), and politically participation (2.5\%). Despite being considered essential for professional practice, no research activity by nurses was observed. Contrary to the literature used for the theoretical foundation of this research, we found that nurses devoted more time to assistance than to management, and that even management activities were directly linked to the assistance dimension since they were related to the management of care. The ESF is a privileged space for the practice of teaching and its insertion in the public service gives nurses more opportunities for political participation. A partnership between universities and healthcare institutions, integrating teaching and the service would put nurses in closer contact with the research dimension.
\end{abstract}

Keywords: Nursing; Professional Practice; Family Health Program; Nursing Administration Research.

\section{RESUMO}

Pesquisa descritiva de caráter qualitativo que utilizou como técnica de coleta de dados a observação sistemática não participante. O estudo teve como objetivo caracterizar as atividades laborais desenvolvidas pelos enfermeiros que atuam na Estratégia Saúde da Família (ESF) em uma unidade de saúde em um município do Sul do Brasil, de acordo com as cinco dimensões do processo de trabalho em enfermagem: participar politicamente, assistir, administrar, pesquisar e ensinar. Foram observadas e registradas as atividades laborais de quatro enfermeiros durante uma semana. Os resultados foram analisados e categorizados de acordo com as cinco dimensões do processo de trabalho do enfermeiro, segundo seu objeto e suas finalidades, respectivamente. Verificou-se que o enfermeiro teve seu tempo mais direcionado para a dimensão assistir (41,9\%), seguido por administrar (32,5\%), ensinar (20\%) e participar politicamente (2,5\%). Embora reconhecida como essencial para a prática profissional, não foi registrada alguma atividade de pesquisa desenvolvida pelos enfermeiros. Em divergência à literatura consultada para a fundamentação teórica desta pesquisa, verificou-se que os enfermeiros dedicaram mais tempo à assistência que à gerência e mesmo as atividades gerenciais estavam diretamente ligadas à dimensão assistir, pois se referiram ao gerenciamento do cuidado. A ESF é um espaço privilegiado para a prática do ensino e a atuação no serviço público confere, ao enfermeiro, mais oportunidades para a participação política. Considera-se que a parceria entre a universidade e as instituições de saúde, integrando o ensino ao serviço, possibilitaria a aproximação dos enfermeiros com a dimensão pesquisar. Palavras-chave: Enfermagem; Prática Profissional; Programa Saúde da Família; Pesquisa em Administração de Enfermagem.

\section{RESUMEN}

Estudio descriptivo de investigación cualitativa que utiliza la técnica de recogida de datos de observación no sistemática participante. El estudio tuvo como objetivo caracterizar las actividades de trabajo realizadas por los enfermeros que trabajan en la Estrategia Salud de 
la Familia (ESF) en una unidad de salud del sur de Brasil, según las cinco dimensiones del proceso de trabajo en enfermería: participación política, atención, gestión, investigación y docencia. Fueron observadas y registradas las actividades laborales de cuatro enfermeras durante una semana. Se analizaron los resultados y se clasifican según las cinco dimensiones del proceso de trabajo de enfermería, de acuerdo con su objeto y sus fines, respectivamente. Se observó que el enfermero emplea más tiempo en la dimensión atención (41,9\%), después en gestión (32,5\%), enseñanza (20\%) y participación política (2,5\%). A considerársela como esencial para la práctica profesional, no se observó ninguna actividad de investigación desarrollada por las enfermeras. En divergencia con la literatura analizada para el fundamento teórico de esta investigación, se constató que los enfermeros dedican más tiempo y ayuda a la gestión, incluso las actividades de gestión están directamente relacionadas con la dimensión atención, porque se referían a la gestión de los cuidados. El FSE es un espacio privilegiado para la práctica de la enseñanza. La actuación en los servicios públicos les confiere a los enfermeros más oportunidades para la participación política. Se considera que la colaboración entre las universidades e instituciones de salud, integrando enseñanza a servicios, permitiría que los enfermeros se acercasen a la dimensión investigación.

Palabras clave: Enfermería; Práctica Profesional; Programa de Salud de la Familia; Investigación Administración de Enfermería.

\section{INTRODUCTION}

The purpose of the Family Health Strategy (FHS) primary health care program is to bring health services closer to the population, with multidisciplinary teams working in a limited region and responsible for developing all actions within their area of coverage. FHS must identify the problems and needs of the families and the community as whole and plan, prioritize and organize health care services.'

Initially, the FHS teams were made up of a nurse, a doctor, a nurse technician, and four to six community health agents (CHAs). As the FHS began to expand, other health workers were incorporated into the work process in addition to the doctor, the nurse technicians and the CHAs. As a result, an important field of work opened for nursing and, consequently, for nurses, who take over the essential role of articulators of the actions developed by the FHS.

Activities assigned to FHS nurses by the Ministry of Health include providing integral care for individuals, families, and communities, which consists in providing direct nursing care, nursing consultations, requesting additional tests and prescribing/transcribing medication.' Nurses are also in charge of monitoring and training CHAs and nurse technicians as well as being co-responsible for planning, managing, coordinating, implementing, and assessing the activities of the Family Health Facilities (USF) ${ }^{2,3}$ The work process of nurses can this be said to assume five complementary and interdependent dimensions: assistance, management, teaching, research, and political participation. ${ }^{4}$

The assistance dimension of the work process aims to provide care, which arises from the demands of individuals, families, social groups, communities, and the collectivity. In the management dimension of the work process, nurses make use of specific tools and aim to organize the work and human resources in nursing. ${ }^{4}$ With regard to the teaching dimension, this study considers the focus on creating, training, and improving human resources in health care, as well as teaching and guiding individuals, families and communities. In the research dimen- sion, nurses work with a view to rethinking their profession by identifying new ways to carry out actions in the pursuit of further knowledge. The political dimension is symbolized by the nursing work force and its social representation. ${ }^{4}$

The relevance and importance of this study stem from the need for scientific output to update and sustain knowledge about the dynamics of the work process of nurses working in the FHS. Hence, this research's theoretical contributions involve identifying which dimensions are required of nurses to develop their activities in the FHS so that they can be recognized to allow nurses to work more effectively, thus making the activity more rewarding for themselves, their teams, patients, and the community.

This study considers the uniqueness of the work processes in nursing and their five different dimensions according to San$\mathrm{na}^{4}$, which may or may not be executed concurrently, aiming to characterize the activities developed by nurses working in the FHS at a health care facility in a city in the South of Brazil.

\section{METHOD}

This is a descriptive, qualitative study that used the systematic non-participant observation technique. ${ }^{5,6}$ It was conducted at a health care facility with four nurses working in the FHS, from March to May 2011 in a city in the South of Brazil. The participants were chosen from the National Register of Health Care Establishments, which detected a multidisciplinary team comprising a total of four nurses.

The ethical aspects were fulfilled using the Free and Informed Consent Form, in compliance with Resolution 196/96 of the Ministry of Health, National Council for Health. The consent was signed by research participants after the study was thoroughly explaned. To ensure anonymity, participants were given the capital letter " $E$ " (for nurse, in Portuguese) and a number, based on when the observation ws carried out, for example, E1, E2, E3, and E4. The project was reviewed and approved by the Research Ethics Committee of the Universidade Federal do Paraná Health Science Department, case 0049.0.091.091-09. 
Each nurse was observed for a week, which roughly corresponds to a 40-hour period per nurse. The amount of hours observed is justified by the fact that the nurses' activities began to repeat at the end of the observation week, which caused data saturation.

The results of the observations were recorded in a semistructured script. Notes were taken about the activities developed, how much time they took and their frequency, for later analysis and categorization. The calculations regarding the distribution of the time nurses spent on each activity were done with aid of an electronic spreadsheet created on the Microsoft Excel(c) 2007 software.

The activities developed by the observed nurses were categorized according to the five-dimension logic required by the work process of FHS nurses, based on their respective objects and aims. ${ }^{4}$ Hence, the description of the activities observed and recorded in the semistructured script served as the basis for analysis and categorization according to the dimensions political participation, assistance, management, teaching, and research, classified according to their object: what is being worked on and can be modified by human actions and their purposes: the reason why the work is done and can be shared by multiple agents working in a team, as described in Figure 1.

\section{RESULTS AND DISCUSSION}

Data collection by systematic non-participant observation totaled 117 hours and six minutes worth of work-related activities. In this study, we chose to include the external actions developed by nurses, such as home visits and meetings in other health care facilities, because these are also regarded as part of nurses' work-related activities. The results are presented according to the following dimensions of the work process of nurses: assistance, management, teaching, political participation, and research.

49:06 hours of observation were logged in the assistance dimension, which corresponds to $42 \%$ of the recorded total. The observed activities were, in order of frequency: nursing consultations, home visits, rounding up of medications for the health care programs, orientation, dispensing medications, reception, scheduling of appointments.

In the analysis of the nurses' managerial work, the management dimension totaled 38:05 hours of observation and corresponded to $33 \%$ of the time they spent on work-related activities. The managerial skills identified were communication (55\%), leadership (33\%), permanent education (8\%), and decision making (4\%)

The teaching dimension corresponded to 23:32 hours, representing $20 \%$ of the total number of activities. In this category, 19:12 hours (81.5\%) correspond to training sessions offered by the City of Curitiba Government for the training of nurses. The remainder consisted of health education activities carried out in the waiting room, which corresponded to $1: 11$ hour (5\%), and orientation given to the staff and users who signed up for specific programs, totaling 3:09 hours (13.4\%).

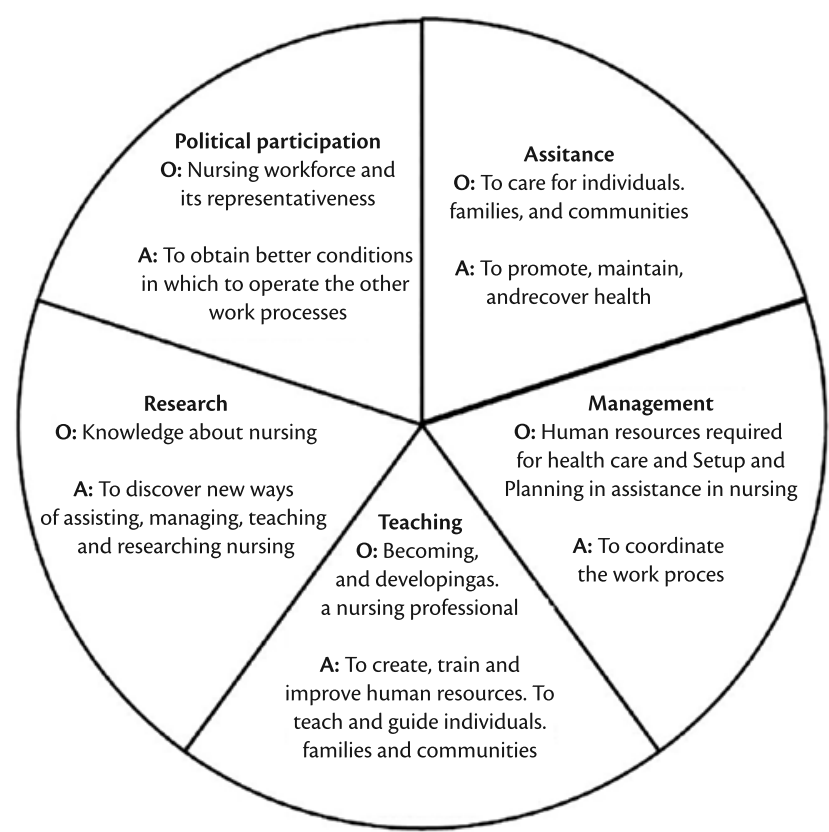

Figure 1 - The five dimensions of the work process of Family Health Strategy nurses, according to Sanna. ${ }^{4}$ Key: $\mathrm{O}=$ Object; $\mathrm{A}=$ Aim. 
The work carried out and classified in the political participation dimension corresponded to 2:53 hours of the observations, that is, $2.5 \%$ of the total of work-related activities. The work observed and classified in this dimension concerns the collaboration for holding the Local Health Conference, a legitimate space for mobilization among the nursing professionals and the community.

Despite being recognized as essential to the professional practice, no research activity by the nurses was observed.

The discussion of the results presented below is based on the characterization of the activities developed by nurses working in the Family Health Strategy at a health care facility in a city in the South of Brazil, following the assistance, management, teaching, and political participation dimensions.

\section{NURSES' ACTIVITIES IN THE ASSISTANCE DIMENSION}

In the assistance dimension, the most frequent activity was nursing consultations to patients of both sexes and in all age groups, registered or not with the health groups (Table 1).

Table 1 - Distribution of work-related activities of nurses at a Family Health Facility, according to the assistance dimension, by time spent on each activity - Curitiba, Paraná, 2011

\begin{tabular}{l|c|c|c}
\multicolumn{1}{|c|}{ Activity } & Frequency & Time (hours) & $\%$ \\
\hline Consultations & 138 & 35,0 & 71,3 \\
\hline Home Visit & 14 & 8,25 & 16,8 \\
\hline Rounding up of Medications & 3 & 1,93 & 3,9 \\
\hline Orientation & 5 & 1,17 & 2,4 \\
\hline Dispensing of Medication & 6 & 1,03 & 2,1 \\
\hline Reception & 3 & 0,53 & 1,1 \\
\hline Scheduling Consultations with & 2 & 0,50 & 1,0 \\
Other Professionals & 2 & 0,68 & 1,4 \\
\hline Others & 173 & 49,06 & 100 \\
\hline Total &
\end{tabular}

Source: prepared by the authors based on the semistructured script.

Table 1 presents two apparently similar items, yet they need to be distinguished. The item "dispensing of medication" refers to the time when the nurse took over the activities of a staff member for a certain period when relocating another staff member from his assignments was not possible due to demand, which does not happen frequently. The item "rounding up of medication" refers to restricted medications. These medications are kept in a closed cabinet and are under the care of nurses, and the act of "rounding up" carried out exclusively by nurses in the facility.

The item "others", with $1.4 \%$ of the occurrences, concerns orientation given to users inside the facility, which was not in- cluded as nursing consultations because they are not systematized. This orientation includes information on sample collection for tuberculosis tests, on vaccine reaction, appointment scheduling, visits by $\mathrm{CHAs}$, among others.

The distribution of health care assistance activities shows that nurses dedicate most of their time to nursing consultations. The legal support for nurses to give consultations, prescribe medicine and request tests is ensured by Law 7,498/86, regulated by Decree $94,406 / 87$ concerning the practice of nursing, as well as Normative Instruction 2/2013, which establishes which medicine prescription, tests, conducts and procedures should be carried out by the nurses of the Curitiba Health Office. ${ }^{2,7}$

Within the scope of the FHS, such conduct is ensured by the National Policy for Basic Health Care, Decree 2,488/11, which, by establishing reviewed set of guidelines and rules for basic health care in the FHS and the Community Health Agents Program (PACS, in Portuguese), also lays down the duties of nurses - to give nursing consultations, request complementary tests and prescribe medications, in conformity with the legal provisions of the profession and in accordance with the protocols or other technical standards, as laid down by the Ministry of Health, at the state, city, or Federal District levesl.'

In line with the relevant legislation, the consensus on the assignments of the nursing staff in primary health care in Curitiba also supports nurses' performing consultations for patients signed up for programs carried out by the health care facilities and requesting tests in accordance with specific protocols. Examples include the Curitiba Mothers Program and the Tuberculosis Control Program. In the Curitiba Mothers Program, nurses assist pregnant women in signing up for prenatal care on their first consultation and request all the necessary tests according to gestational age, in compliance with protocols. In the Tuberculosis Control Program, nurses request sputum culture tests for all patients with respiratory symptoms. ${ }^{3}$

The second most frequent item are home visits. The Ministry of Health defines that each FHS team should be in charge of monitoring an average of 3,000 people, not exceeding 4,000 people. The studied territory has approximately 12,800 people and the distribution of the number of users was based on the average of 828 households and 2,986 users per team. According to the FHS criteria, the number of users per team is adequate, but two low-cost residential condominiums with an average 400 housing units each are planned for the area, with expected increase in the population of approximately 3,200 users, thereby upsetting the current distribution.

Home visits are a crucial intervention tool in the FHS so as to assess the families conditions within the coverage area, important data to set up the population's epidemiological profile. To differentiate it form a social call, a home visit must be 
planned and systematized, which comprises planning, implementation, data recording and process evaluation. ${ }^{8}$

8:15 hours were spent on this activity in the period observed, which corresponds to $16.8 \%$ of the assistance dimension total. One of the nurses did not take part in home visits during this period, so the total refers to the actions of only three nurses. It should be noted that there were times when the nurses were unable to make home visits and leave the health care facility due to high demand.

The home visits were made to patients in the hypertensive and diabetic programs, to neonates, bedridden elders, patients in the mental health program and for fetal death research, among other activities.

At the studied health care facility, home visits are made by the nurse following the appointments made by the CHAs and nurse technicians in the team in charge of a specific coverage area, who are also in charge of briefing nurses are briefed on the purpose of the visit. Appointments follow priority groups, such as neonates, bedridden elders, and diabetic and hypertensive patients.

Nurses also monitor the visits made by the $\mathrm{CHAs}$ and perform active searches in the information systems for absent patients in the programs or who missed consultations, among others. This information is then forwarded to the CHAs so they can prioritize their home visits.

\section{NURSES' ACTIVITIES IN THE MANAGEMENT DIMENSION}

The health care facility has one nurse, who is the local health authority and manages the family health facility as a whole. Working as the authority manager in the facility should allow the nurse to focus on providing direct care to patients. In the period observed most of the time the nurses were indeed focused on assistance.

This context contrasts with studies carried out in other places, in which management comes first and the nurse's primary role is to manage the health care facility. ${ }^{9}$ It should be stressed that even the management work described here refers to the management of assistance/care.

The nurses' activities were characterized in the management dimension of the work process, according to the percentage of time spent on each activity (Table 2).

The item with the highest number of occurrences is the feeding of information systems. An information system is an ordered set of means of action or ideas with a view to achieving a result. Through health information systems it is possible to access records of patients, socioeconomic backgrounds, productivity of the different professionals of the health team, epidemiological profiles, mortality rates, birth conditions, among others. ${ }^{10}$
Table 2 - Characterization of nurses' work-related activities at a Family Health Facility according to the management dimension, by time (hours) spent on each activity - Curitiba, Paraná, 2011

\begin{tabular}{l|c|c|}
\multicolumn{1}{|c|}{ Activity } & Time (hours) & $\%$ \\
\hline Feeding of information systems & 9,48 & 25,73 \\
\hline Team Meetings & 5,30 & 14,44 \\
\hline $\begin{array}{l}\text { Meetings to decide targets of vaccination } \\
\text { campaigns }\end{array}$ & 4,00 & 10,50 \\
\hline Supervision meeting for the mental health program & 3,00 & 7,88 \\
\hline Making of nursing staff rota & 2,02 & 5,34 \\
\hline Issuing reports & 1,52 & 4,95 \\
\hline Active search of patients in the computer system & 1,31 & 4,03 \\
\hline Event/case discussion in each area & 1,22 & 3,63 \\
\hline Request for admission via central admissions & 1,22 & 3,63 \\
department (CMUM, In Portuguese) & 1,19 & 3,43 \\
\hline Referrals to other professionals & 1,15 & 3,28 \\
\hline Organizing materials and equipment & 1,15 & 2,84 \\
\hline Requesting ambulance & 1,05 & 2,71 \\
\hline Checking the monitoring of neonates & 1,02 & 1,75 \\
\hline Checking/receiving medication & 0,40 & 1,31 \\
\hline Control of materials & 0,30 & 0,66 \\
\hline Rescheduling medical appointments & 0,15 & 0,44 \\
\hline Answering complaints & 0,10 & 0,13 \\
\hline Contacting users by telephone & 0,03 & 3,28 \\
\hline Other occurrences & 38,05 & $100 \%$ \\
\hline Total & & \\
\hline Source prepar & & \\
\hline
\end{tabular}

Source: prepared by the authors based on the semistructured script.

An institution that uses the information system adequately possesses an important management tool. It can become aware of problems and look for ways to solve them by setting feasible goals and objectives within its reality. Health information offers decisive support to retrieval of information regarding socio-economic, demographic, and epidemiological realities, for planning, management, organization and assessment in the different layers that constitute the Unified Health System. Information systems are essential in the decision-making process. They are management tools that nurses should seize and explore to their full potential."

The other items with greater frequency concern team meetings or meetings held in the Sanitary District. During these meetings, the coordinators of a particular sector or program meet the heads of each health care facility within scope of the Sanitary District to pass on information or discuss the implementation of specific activities in the Health Care Facility. Hence, they concern the District's supervision over the activities carried out by the Facility and are not regarded as teaching activities.

The team meetings are use to discuss work methods. They are an important space for interaction and resolution of prob- 
lems detected in the work routine. The work on family health is primarily done in teams, and the different professionals who make up the FHS must work in an integrated way so as to meet the community's health needs.

To develop the work process according to the management dimension, the nurse in our study scenario develops specific skills and roles: the management roles, which include planning, coordination, direction and control; and the management skills, which include the decision-making process, communication, leadership, and continuing education.

In addition to the above-mentioned general skills, specific skills include negotiation, conflict management, people management, materials management, time management, information management, and teamwork. It was within this framework that the roles performed in the management dimension of the nurse's work we analyzed, as presented below.

Control activities include searching the computerized system for inactive or absent patients, recording test results, checking medications, issuing reports, controlling dispensed medication and checking any pending issues in the micro areas.

The coordination-related activities include requesting transportation, answering complaints, attending team meetings, receiving and storing consumables, making the staff rota, requesting admission, managing openings in the medical appointment schedule.

Planning activities refer to the nurse's participation in a meeting to plan actions, including vaccination campaigns, to organize materials and equipment for the different activities.

We also observed team meetings called upon by the local health authority, but these were held separately for each profession.

Meetings are important for team interaction, for sharing experiences and information and also, in the context of the FHS, for establishing guidelines for the work by area. We believe it is important to ensure that all FHS team members attend these meetings, including those who work more directly in oral health, so as to turn these meetings into productive spaces for dialogue and negotiation.

Team meetings are extremely important in the FHS because allow the voicing of opinions, building projects and plans for collective care within the prospect of teamwork. Studies mention meetings as a space for interaction and dialogue, in which workers can express their expectations about one another, especially those that are not openly discussed elsewhere.12

As indicated, the activities developed by the nurses in this study concern exclusively assistance management; and the activities that were classified as control and coordination directly concern the concentration of efforts to maintain the quality and continuity of assistance.

Characterizing the management process according to management skills, communication and leadership are seen as most commonly used in the professional practice. Permanent education refers to the time devoted to training for implementing a protocol of risk classification, an activity carried out jointly with all the team members. The protocol should be implemented following a directive issued by the central level for all facilities within the health care network.

In this study, communication stands out as a central element interconnecting all managerial processes. This finding is corroborated by the literature, which establishes communication as one of the main points needed to carry out management activities. A leader's success depends on his or her ability to communicate, since communication is a means to reach other people and bring them to action. ${ }^{13}$

Leadership was identified in this study as the second most frequent skill developed by nurses and is related to people management, time management, and negotiation. As mentioned above, some authors consider these two elements jointly due to of the importance of communication skills for leadership development.

The development of these skills is dynamic and inter-related. An example would be the organization of daily rota of activities. Despite being a people management activity, it involves negotiation between professionals and conflict management, which can occur when one a worker disagrees with their allocated function.

\section{NURSES' ACTIVITIES IN THE TEACHING DIMENSION}

The data on the teaching dimension reveal that education in health and receptiveness is underused. Patients' waiting time, from arrival at the facility until they are seen by the professionals, is long and idle, which often causes anguish, anxiety, anger, and negative comments about the services offered at the facility.

The waiting period can be used as a moment of productive work with health education practices and interaction between patients and health care staff. It should be stressed that this is not exclusively a nursing space and that it could be used by all professionals.

Health programs set up to provide care for specific disease groups, like hypertension and diabetes, are a guideline of the FHS work and in this facility the health education activities of these programs are operated by nurse technicians as an activity delegated by the nurses. The nurse develops his role as an educator during the nursing consultation. The Tobacco Control Program has been very active and works in conjunction with a dentist, carrying out interviews to include new patients, holding the group meetings and monitoring the signed-up patients during the treatment period. ${ }^{1.3}$. 
We did not verify any teaching activities aimed at the team in a systematic manner, but instead guidelines put into effect as the service progressed through questions about the procedures performed, signaled by the professional, or through observation carried out by the nurse.

\section{NURSES' ACTIVITIES ACCORDING TO THE POLITICAL PARTICIPATION DIMENSION}

The work observed and classified in this dimension corresponds to the collaboration for implementing the Local Health Conference. To make the conference happen, all the staff of the health care facility were mobilized The staff joined sectors of the civil society and other existing bodies in the territory, besides negotiating with the civil society itself.

Historically, the Unified Health System (SUS) is a rich space for experiences of political struggle as it was conceived after a long process of popular pressure and the sanitary reform movement. ${ }^{14}$

One of the principles of the SUS is social control, with the Health Conference acting as one of the collegiate bodies through which such control is effected, as stipulated by Law 8,142 of December, 28, 1990.15 Another body is the Health Council, whose members include representatives of health care users, directors, health care providers and staff, who strive to create strategies and superve the execution of health policies. ${ }^{3}$ Because it is closer to the community, the Local Health Council has the potential for conflict, but it is very rich for discussing the issues related to the health care facility and the service it provides the population.

Inserted in the context of public health care, it is impossible not to be politically engaged because all health care practice is directly related to the decisions taken at the strategic level. One example of this is the Annual Operating Plan (AOP), an instrument that translates the outcome of the negotiations between the Health Care Facility and the Sanitary District based on the Municipal Health Plan and the Annual Schedule of Health, and which takes local variables into account, such as the characteristics of the territory, available resources, and the building of the teams, in order to set the health care goals. ${ }^{16}$

The outcomes of these negotiations are felt in the work routine, which will have to be adjusted so the goals can be achieved. Failure to achieve a satisfactory index could mean that workers might not attain the percentage of quality incentive by the deadline.

This incentive to productivity linked to a reward can lead workers to psychological exhaustion since they begin to work toward the goal, prioritizing quantity over quality of service, in addition to making them anxious about achieving the goals.

Mental stress at work is a result of the organization of the work itself. The division of labor, the content of the task, the hi- erarchy, the command, the responsibility, the power relations, among other factors, and the greater or lesser ability of workers to interfere on the contents of their work can impact their health, leading them to experience mental distress. ${ }^{17}$

This study does not aim to discuss the impact of management policies on the health of workers, but only to record the importance of political engagement to the discussion of issues affecting workers who take part in the existing collegiate bodies. The fight for better conditions is, to a large extent, also in the best interest of users of the system, since the workers are also going to be collaborating toward improvements and advances in the SUS. They also constitute the foundation upon which programs and projects, actions and health services available to the population can be implemented.18,19

\section{FINAL CONSIDERATIONS}

In this study, we characterized the activities of nurses according to the five dimensions of the work process. Based on the literature consulted previously, we believe that nurses would spend the greater part of their time in activities belonging to the management dimension. We found, however, that nurses spent more time on assistance than on management. We also found that the management activities were directly related to assistance. We related this finding to the existence of the local health authority, whose task is to manage the Family Health Facility as a whole and free the nurses to focus on their own specific tasks.

The classification of items revealed that the assistance and management dimensions are very closely articulated and that, when working on the managerial activities, nurses also practice assistance. At times this articulation between the dimensions of the work process was a hindrance to the classification of the nurse's practices. This led the authors to return to the notes and rethink to what extent one or another activity could be inserted.

The FHS is a privileged space for teaching and nurses use education as a form of care in this context, targeting users individually or in groups. A shortcoming in this dimension was the lack of systematized permanent educational activities for the work team members.

Nurses working in the public sector, and more specifically in basic care, appear to have many opportunities to participate politically. To develop their work, they participate in the Local Health Council and the Local Health Conference and negotiate with other entities, for instance the Guardianship Council, schools, day care centers, and the Social Service Center. We found no instances of nurses negotiating with external bodies, such as the Sanitary District and the Municipal Department of Health, in favor of their professional interests.

The study did not find the research dimension to be a reality in the health care facility, which allows us to assert that fur- 
thering knowledge is not a priority in the service, which focuses on practice. The workers are, therefore, restricted to their daily routine of health care delivery and achieving institutional goals, which does not allow them to create new strategies and new ways of developing their work. We maintain that a partnership between the university and health institutions, as a way of integrating teaching and the service, would put nurses in closer contact with scientific research. This arrangement has been used as a field of practice for some time now and it was expected that the team would be inserted in the research dimension.

It must be acknowledged that, although the research participants have cooperated to complete the study exceptionally well and the results have revealed important aspects of the work process of FHS nurses, this research was carried out in a single Family Health Facility, with its own special features and peculiarities. Hence, it is imperative that further studies are carried out in different health care facilities and with more nurses so that the knowledge about his topic can be expanded.

\section{REFERENCES}

1. Brazil. Portaria no $2.488 / 2011$ de 21 outubro de 2011. Passes the National Policy for Basic Health Care, establishing a review of guidelines and standards for setting up basic health care for the Family Health Strategy (FHS) and the Community Health Agents Program (PACS). [Cited 2013 Sept 20]. Available from: http://189.28.128.100/dab/docs/publicacoes/geral/pnab.pdf

2. Curitiba. Secretaria Municipal da Saúde. Normative Instruction 2, December 11, 2013. Sets medicine prescription, tests, conduct, and procedures for the nurses of the Curitiba Municipal Department of Health. [Cited 2013 Sept 20]. Available from: http://www.saude.curitiba. pr.gov.br/index.php/ letter-ofSus/instruction-normative-of-nursing

3. Curitiba. Municipal Department of Health Consenso sobre as Atribuições de Enfermagem na Atenção Primária à Saúde de Curitiba. Curitiba (PR): Prefeitura Municipal de Curitiba; 2012.

4. Sanna MC. Os processos de trabalho na Enfermagem. Rev Bras Enferm. 2007 mar/abr; 60(2):221-4.
5. Minayo MCS. O desafio do conhecimento: pesquisa qualitativa em saúde 12. ed. São Paulo: Hucitec; 2012.

6. Pope C, Mays N. Pesquisa qualitativa na atenção à saúde. 3. ed. Porto Alegre: Artmed; 2009

7. Brasil. Lei no 7.498 de 25 de junho de 1986. Dispõe sobre o Exercício da Enfermagem, e dá outras providências. [Cited 2010 Sept 20]. Available from: http://www.corenpr.org.br/legislacao.

8. Santos EM, Morais SHG. A visita domiciliar na Estratégia da Saúde da Família: percepção de enfermeiros. Cogitare Enferm. 2011 jul/set; 16(3):492-7.

9. Haussmann $M$, Peduzzi $M$. Articulação entre as dimensões gerencial e assistencial do processo de trabalho do enfermeiro. Texto Contexto Enferm. $2009 \mathrm{abr} / j u \mathrm{n} ;$ 18(2):258-65.

10. Brasil. Ministério da Saúde. Auditoria no SUS: noções básicas sobre sistemas de informação. Brasília (DF): Ministério da Saúde; 2004.

11. Carvalho ALB. Informação em saúde como ferramenta estratégica para qualificação da gestão e fortalecimento do controle social no SUS. Tempus Actas de Saúde Coletiva. 2009 jul/set; 3(3):16-30.

12. Grando MK, Dall'agnol CM. O processo grupal em reuniões de equipe no PSF. Esc Anna Nery Rev Enferm. 2010 jul/set; 14(3):504-10.

13. Pontes AC, Leitao IMTA, Ramos IC. Comunicação terapêutica em Enfermagem: instrumento essencial do cuidado. Rev Bras Enferm. 2008; 61(3):312-8

14. Vieira FS. Avanços e desafios do planejamento no Sistema Único de Saúde. Ciência \& Saúde Coletiva. 2009; 14(1):1565-77.

15. Brasil. Ministério da Saúde. Conselho Nacional de Saúde. Coletânea de Normas para o Controle Social no Sistema Único de Saúde. $2^{a}$ ed. Brasília: Editora do Ministério da Saúde; 2006.

16. Curitiba. Secretaria Municipal de Saúde. Relatório Anual de Gestão 2008. Curitiba, 2009. (Cited on September 20, 2014). Available at: http://sitesms. curitiba.pr.gov.br/saude/sms.pdf

17. Santos APL, Galery AD. Controle sobre o trabalho e saúde mental: resgatando conceitos, pesquisas e possíveis relações. Cad Psicol Soc Trab. 2011; 14(1):31-41.

18. Brasil. Ministério da Saúde. Conselho Nacional de Saúde. Princípios e diretrizes para a gestão do trabalho no SUS (NOB/RH-SUS). $3^{\text {a }}$ ed. Brasília: Editora do Ministério da Saúde; 2005.

19. Silveira MR, Sena RR, Oliveira SR. O processo de trabalho das equipes de saúde da família: implicações para a promoção da saúde. REME - Rev Min Enferm. 2012 abr/jun; 15(2):196-201. 